\title{
DOSAGE OF LACTATE IN THE CEREBROSPINAL FLUID IN INFECTIOUS DISEASES OF THE CENTRAL NERVOUS SYSTEM
}

\author{
Hideraldo Luis Souza Cabeça ${ }^{1}$, Hélio Rodrigues Gomes², \\ Luís dos Ramos Machado ${ }^{3}$, José Antonio Livramento ${ }^{4}$
}

\begin{abstract}
This paper analyzes the diagnosis aid of the dosage of lactate in the cerebrospinal fluid (CSF) in infectious diseases of the central nervous system (CNS). We analyzed prospectively 130 samples of CSF of 116 patients with diagnoses of infectious processes in the CNS. The 130 samples of CSF were divided into five groups: 28 samples of the control group, 40 of bacterial meningitis, 22 of viral meningitis, 16 of fungal meningitis and 24 of patients presenting acquired immune deficiency syndrome (AIDS). The concentration of lactate in the CSF was elevated in the group of patients with bacterial meningitis (average $=46.2 \mathrm{mg} / \mathrm{dL}$ ), fungal meningitis (average $=27.3 \mathrm{mg} / \mathrm{dL}$ ) and in the AIDS group (average $=23.5 \mathrm{mg} / \mathrm{dL}$ ). In the control group and viral meningitis group the lactate content in the CSF presented the reference rates according to the employed method. The lactate dosage in the CSF presented a negative correlation with glycorrhachia and positive correlation with the cellularity and total proteins of the CSF. We conclude that the lactate dosage in the CSF, although unspecific, helps to distinguish the infectious processes of the CNS.
\end{abstract}

KEY WORDS: lactate, cerebrospinal fluid, central nervous infections.

\begin{abstract}
Dosagem de lactato no líquido cefalorraqueano em moléstias infecciosas do sistema nervoso central
RESUMO - O presente estudo tem como objetivo analisar o auxílio diagnóstico da dosagem do lactato no líquido cefalorraqueano (LCR) em moléstias infecciosas do sistema nervoso central (SNC). Foram estudadas, de modo prospectivo, 130 amostras de LCR de 116 pacientes com diagnóstico de processos infecciosos do SNC. As 130 amostras de LCR foram distribuídas em cinco grupos, sendo: 28 amostras controles, 40 meningite bacteriana, 22 meningite viral, 16 meningite fúngica e 24 pacientes com a síndrome da imunodeficiência humana adquirida (SIDA). A concentração do lactato no LCR estava elevada no grupo de pacientes com meningite bacteriana (média=46,20 $\mathrm{mg} / \mathrm{dL}$ ), meningite fúngica (média $=27,37 \mathrm{mg} / \mathrm{dL}$ ) e no grupo SIDA (média $=23,54 \mathrm{mg} / \mathrm{dL}$ ). Nos grupos controle e de meningite viral o teor de lactato no LCR encontrava-se entre os valores de referência para o método utilizado. A dosagem do lactato no LCR apresentou correlação negativa com a glicorraquia, e positiva com a celularidade e proteínas totais do LCR. Em conclusão, a dosagem do lactato no LCR, apesar de inespecífica, auxilia na distinção entre processos infecciosos do SNC.
\end{abstract}

PALAVRAS-CHAVE: ácido láctico, líquido cefalorraqueano, infecções do sistema nervoso central.

Thestudy of infectious and inflammatory pathologies of the central nervous system (CNS) has always raised a great interest from the scientific community, for the epidemiological characteristics of some of them or for the sequelae that they can generate if not diagnosed and treated in time. The cerebrospinal fluid (CSF) plays a major role in the evaluation of the natural history, in the diagnosis and in the follow-up of the infectious and inflammatory pathologies of the $\mathrm{CNS}^{1-3}$. In many cases, the routine evaluation of the CSF is not sufficient for diagnosing the type of meningitis ${ }^{4-6}$. Menninger, in 1924, found elevated values of lactate (LA) in CSF from patients with bacterial meningitis ${ }^{7}$. Posner and Plum (1967) confirm the independence of LA in blood and in CSF and conclude that the LA in CSF is a good indicator of the cerebral metabolism ${ }^{7,8}$. The LA is a product of the metabolism of the carbohydrates by anaerobic via. From a molecule of glucose, successive reactions lead to a production of molecules of pyruvic acid in the cellular cytoplasm 9 . In anaerobic conditions the pyruvic acid turns into LA, by the action of the lac-

Centro de Investigações em Neurologia, UM 15, Departamento de Neurologia da Faculdade de Medicina da Universidade de São Paulo. (FMUSP) São Paulo SP, Brasil: ${ }^{1}$ Mestre em Neurologia; ${ }^{2}$ Doutor em Neurologia; ${ }^{3}$ Professor Assistente em Neurologia; ${ }^{4}$ Livre Docente de Neurologia.

Received 30 May 2001, received in final form 20 July 2001. Accepted 25 July 2001.

Dr. Hideraldo L.S. Cabeça - Pça. Amadeu Amaral 47 / 33 - 01327-010 São Paulo SP - Brasil. FAX: 5511 289-8879. E-mail: Isflcr@ terra.com.br 
tate dehydrogenase enzyme $(\mathrm{DH})$ and the nicotinamide adenine dinucleotide reductase $\left(\mathrm{NADH}_{2}\right)$. This action is reversible so that, if the conditions of oxygen uptake are reestablished the prior reaction invert itself and the LA turns again into pyruvic acid and this into acetyl Coenzime $A$, which finally incorporates to the Krebs cycle ${ }^{10}$.

The study of Kleine et al. was primordial for the improvement of the enzymatic method to determine the LA in CSF ${ }^{11}$. Most studies indicate normal contents of LA in CSF until 19mg/dL ${ }^{12,13}$; in cases of bacterial and fungal meningitis the contents of LA would be higher than $30 \mathrm{mg} / \mathrm{dL}$ and in viral meningitis inferior to $25 \mathrm{mg} / \mathrm{dL}$ or contents according to normali$\mathrm{ty}^{12}$. When an infectious process occur, the greater affluence of leukocytes increases the metabolism of glucose ${ }^{14}$. Besides, there is a greater anaerobic metabolism, products of arachidonic acid and the liberation of free radicals and liberation of the tumor necrosis factor-alpha (TNF- $\alpha$ ) ${ }^{15}$. Hypoglycorrhachia and the increase of the LA in CSF during meningitis originate primarily from the increase of the anaerobic glycolysis in the subarachnoid space and these metabolic disorders are induced by the TNF- $\alpha$ and by the leukocytes ${ }^{16}$.

This study aims to evaluate the lactate levels in the CSF of patients with bacterial, viral, fungal meningitis, in the acquired immunodeficiency syndrome (AIDS) and in control cases, checking the relationship of lactate, cellularity, glucose and total proteins.

\section{METHOD}

A total of 130 samples of CSF from 116 patients of the Medical School of the University of São Paulo, Infectious Nervous System Division were prospectively analyzed in the time period between May, 1996 and January, 2000.

All the CSF samples were analyzed for total cell count; cytomorphologic assay; basic biochemical assay (concentration of total proteins and glucose); dosage of lactic acid; ${ }^{17}$ general immunoassays (VDRL and reactions of complement fixation tests for syphilis and cysticercosis); microbiologic assay (direct bacteriologic, mycobacteriologic and mycologic assays, as well as the adequate cultures) ${ }^{18}$ as necessary; immunologic complementary specific assays as indicated.

For lactate determination, the CSF samples were processed according to the enzymatic method without prior deproteinization, employing the reactive commercial kit Lact-Boeheringer Mannheim ${ }^{19}$. The analyze of the LA were performed in a maximum period of 48 hours after collecting the CSF. The CSF was stored in a refrigerated environment with temperatures between 4 to $8 \mathrm{o} C$, because it was reported that values of LA were altered in the CSF if it is kept in environmental conditions, without an adequate storage ${ }^{17}$. Values between 11 and $19 \mathrm{mg} / \mathrm{dL}$ were considered within the reference limits for this method ${ }^{11}$.

The Ethics Committee of the University of São Paulo Medical School has approved this study.

Samples were distributed in five groups, according to diagnosis: (1) control group, with 28 samples; (2) bacterial meningitis, with 40 samples; (3) lymphocytic viral meningitis, with 22 samples; (4) fungal meningoencephalitis with 16 samples; (5) patients with AIDS presenting antiHIV in CSF and in blood serum, with 24 samples.

Statistical analysis - At first all the variables were analyzed descriptively. It was performed the measurement of averages and standard deviations and medians (SD). Non parametric test were preferentially employed. For the study of the correlation among the studied variables the Spearman Correlation Coeficient was used. The significance level (alpha) used for all the tests was $10 \%$. This value was chosen due to the intrinsic characteristics of the studied material.

\section{RESULTS}

From the total of 130 samples studied, 71 (54.6\%) were from female patients and 59 (45.4\%) from male patients. Ages ranged from 2 days to 82 years, not presenting a significant difference from the statistical point of view to the analysis of the five groups $(p=0.5419)$.

Cellularity study among groups evidenced pleocytosis in all groups, except the control group. This analysis showed a significant statistical difference $(p<0.0001)$. It was observed an increase of contents of total proteins in all groups, except the control group, showing a significant difference from the statistical point of view $(p<0.0001)$.

The glucose concentration was evaluated statistically among the five groups, and had a significant value from the statistical view $(p<0.0001)$, presented in Table 1. In this table the average of glycorrhachia is inferior to normality in samples of patients with fungal and bacterial meningitis and in patients with AIDS. Patients of the control group and the viral meningitis group presented an average with values compatible to normality.

Table 2 shows the values of lactate in the five groups. The analysis of lactate in the different studied groups showed average values above normality in the groups of fungal and bacterial meningitis and in patients with AIDS. In the control and viral meningitis groups we observed lactate values consistent to normality. The evaluation of the five groups showed a significant statistical difference concerning the lactate averages $(p<0.0001)$.

The groups were compared as for the statistical significance in relation to the dosages of glucose and 
Table 1. Glucose concentration in CSF: average, standard deviation, median, minimum and maximum values $(\mathrm{md} / \mathrm{dL})$.

\begin{tabular}{lcccccc}
\hline Variables & $\mathrm{N}$ & Average & SD & Median & Minimum & Maximum \\
\hline Fungal meningitis & 16 & 21.4 & 14.9 & 22 & 1 & 56 \\
AIDS & 24 & 35.1 & 15.7 & 36 & 4 & 67 \\
Bacterial meningitis & 40 & 20.2 & 21.4 & 16 & 1 & 114 \\
Viral meningitis & 22 & 51.8 & 15.1 & 51 & 28 & 79 \\
Control & 28 & 60.0 & 7.6 & 60 & 47 & 77 \\
\hline
\end{tabular}

Kruskal-Wallis test: $\mathrm{p}<0,001 ; \mathrm{N}$, number of samples; SD, standard deviation.

Table 2. Lactate concentration in CSF: average, standard deviation, median, minimum and maximum values $(\mathrm{mg} / \mathrm{dL})$.

\begin{tabular}{lcccccc}
\hline Variables & $\mathrm{N}$ & Average & SD & Median & Minimum & Maximum \\
\hline Fungus & 16 & 27.3 & 12.8 & 26.5 & 12 & 48 \\
AIDS & 24 & 23.5 & 10.1 & 21.5 & 10 & 49 \\
Bacterial meningitis & 40 & 46.2 & 33.5 & 34.5 & 10 & 150 \\
Viral meningitis & 22 & 17.2 & 5.6 & 15.5 & 7 & 33 \\
Control & 28 & 12.6 & 3.3 & 12.5 & 4 & 19 \\
\hline
\end{tabular}

Kruskal-Wallis test: $p<0,0001$. N, number of samples; SD, standard deviation.

Table 3. Paired analysis of the groups showing the glucose average in CSF (mg/dL).

\begin{tabular}{lcccc}
\hline Groups & AIDS & Bacterial meningitis & Viral meningitis & Control \\
\hline Bacterial meningitis & + & + & + & + \\
Viral meningitis & + & + & & + \\
Fungal meningitis & - & - & + & + \\
AIDS & & + & + & + \\
\hline
\end{tabular}

$\mathrm{P}<0,0001 ;+$, significant statistical difference; -, there is no significant statistical difference.

Table 4. Paired analysis of the groups showing lactate average in CSF (mg/dl).

\begin{tabular}{lcccc}
\hline Groups & AIDS & Bacterial meningitis & Viral meningitis & Control \\
\hline Bacterial meningitis & + & + & + & + \\
Viral meningitis & - & + & & - \\
Fungal meningitis & - & - & - & + \\
AIDS & & + & - & + \\
\hline
\end{tabular}

$\mathrm{P}<0,0001 ;+$, significant statistical difference; -, there is no significant statistical difference.

lactate in CSF. Table 3 shows a paired analysis of the groups in relation to the average of glucose in CSF. The paired analysis in groups concerning the lactate dosage in CSF may be observed in Table 4.

Figure 1 shows a negative correlation between the averages of glucose and of lactate in CSF in samples from patients with bacterial meningitis. Thereby the increase of glycorrhachia implies the decrease of the lactate levels, and the opposite is also true. This correlation has a statistical significance.

\section{DISCUSSION}

Due to high morbidity and mortality of many infectious diseases which attack the CNS, laboratory tests have been gauged so that they can establish an early etiologic diagnosis of these diseases. In this 


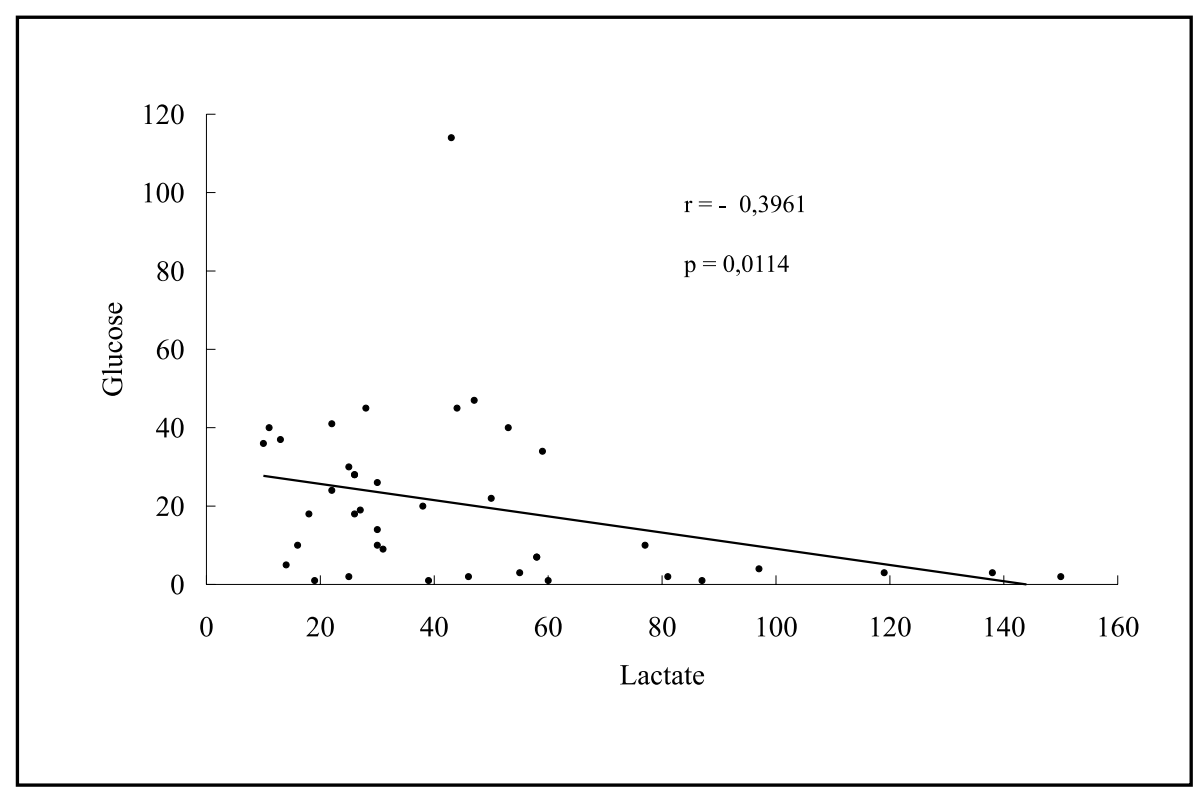

Fig 1. Correlation glucose/ lactate in the CSF in bacterial meningitis.

context, although little specific by definition, some laboratory tests are extremely important because they can delimit in a valuable manner the field of diagnostic uncertainty. Among these tests, the one for determination of the lactic acid levels is among the most used ${ }^{20}$.

In this study five groups of patients were analyzed and compared or related: four with infectious pathologies of the nervous system and a control group, a total of 130 samples analyzed. There were no differences which could represent restrictions to the interpretation of the results as for the distribution of the casuistry concerning age and gender.

Cellularity behaved as expected, presenting pleocytosis in all groups except in the control group, such as the total proteins, which presented elevated rates in all groups, except the control group. Glycorrhachia is one of the important elements in diagnosis of infectious processes of the nervous system. As classical, bacterial meningitis and fungal meningoencephalitis were followed by hipoglycorrhachia: (1) in bacterial meningitis, the average was $20.2 \mathrm{mg} / \mathrm{dL}$; (2) in fungal meningoencephalitis, the average was $21.4 \mathrm{mg} / \mathrm{dL}$. In the group of patients with AIDS we observed a significant dispersion of the values of glychorrhachia. As for the viral meningitis group, although the average values of glycorrhachia in this group are within normal ranges, it was unusual that some patients presented hypoglycorrhachia. These samples were not excluded because, although it is virtually impossible to follow information about the evolution of these patients, the diagnostic yield when the collection was done left no doubt on the benign nature of the process.

The glucose dosage in CSF is of crucial importance in diagnosis and control of the evolution of many infectious diseases of CNS. Meanwhile, the strict relationship between glychorrhachia and glycemia with a short time interval mediating the chemical equilibrium between the two of them ends up bringing some difficulties to the interpretation in the CSF exam ${ }^{21,22}$.

There is an evident correlation among the glucose levels and LA levels ${ }^{23}$. The elevation of the LA in CSF is related to the decrease in the contents of glycorrhachia and vice versa ${ }^{24}$, especially in bacterial meningitis and micosis, of the CNS. Furthermore, the LA shows reference intervals with better defined limits concerning to glycorrhachia ${ }^{4,25}$. In diabetic patients, the dosage of LA is not related to the levels of glycemia in a linear manner ${ }^{7,9}$. Without influence of the blood LA, the determination of LA in CSF provides important information in the evaluation of diabetic patients or in cases which glycorrhachia can not be of any help ${ }^{23,26}$.

The average of LA content found in the bacterial meningitis group ( $46.2 \mathrm{mg} / \mathrm{dL}$ ) was the higher of the five groups analyzed. Next one was fungal meningitis $(27.3 \mathrm{mg} / \mathrm{dL})$ and after that the AIDS group (23.5 $\mathrm{mg} / \mathrm{dL}$ ). These values are significantly above normality standard.

The average of LA values found in the CSF of the viral meningitis and control groups does not differ 
significantly of the values of normal reference (until $19 \mathrm{mg} / \mathrm{dL}$ ). In the viral meningitis group, the maximum value of LA found in CSF was $33 \mathrm{mg} / \mathrm{dL}$. Viral meningitis cases, in the initial phase of diagnostic yield, with levels of LA in CSF above the reference values are mentioned in the literature ${ }^{27}$.

In fungal meningitis the maximum value found was $48 \mathrm{mg} / \mathrm{dL}$ and corresponds to a sample whose diagnosis was CNS histoplasmosis.

Among the AIDS group samples, the values referring to the dosage of LA in CSF presented dispersion. This dispersion is expected due to the multiplicity and diversity of diseases, with or without a defined diagnosis, which can comprise the AIDS patients. There was no statistical difference among the levels of LA observed in the samples from AIDS patients which were submitted to CSF analysis due to complaint of cephalea or with opportunist associated established disease. The literature does not present a support for the adequate interpretation of the results of LA in CSF in patients with reagent antibodies anti-HIV. The LA levels in this group are higher than the basal (there is statistical difference concerning the control group).

In bacterial meningitis, the values of LA in CSF vary from 10 to $150 \mathrm{mg} / \mathrm{dL}$. The average recorded for this group $(46.2 \mathrm{mg} / \mathrm{dL}$ ) is compatible to what are reported in studies about this subject ${ }^{24,28}$. From 40 samples evaluated in the bacterial meningitis group, 32 presented a percentage of neutrophil cell higher than $50 \%$ in the cytomorphologic profile, associated to LA contents superior to $19 \mathrm{mg} / \mathrm{dL}$. In this casuistry the LA levels recorded for bacterial meningitis were significantly higher than the ones observed in the viral meningitis group, the AIDS group and the control group.

In fungal and bacterial meningitis there is negative correlation between the glucose and the LA in CSF; while one increases the other decreases ${ }^{24}$. In this study we found a negative correlation between the glucose and LA in CSF, which corroborates the prior observation. Among the cells with glycolytic capacity, those, which can be a source of LA, are: leukocytes, tumor cells, neurons, glial cells, as well as fungi 29,30 .

Low values of LA do not exclude the diagnosis of bacterial meningitis ${ }^{31}$. Isolated dosages may present reduced values due to circumstantial factors, therefore the interpretation must always be done in the context of the remaing of the CSF exam. Persisting the doubt, it is a consensus in literature to repeat the dosages in a second CSF exam, in order to exclude the possible causes of non systematic error ${ }^{12,32}$.

Analyzing the data presented we may recommend the dosage of LA in CSF in cases of suspicion of CNS infection, mainly in the screening of bacterial and viral meningitis, as well as a helping measurer in the clinic and therapeutic evolution.

\section{CONCLUSIONS}

After analyzing 130 samples of cerebrospinal fluid from 116 patients it is possible to conclude that ${ }^{33}$ : (1) in the studied pathologies the lactate level in CSF behaved inversely proportional to glycorrhachia; (2) the lactate levels in CSF in the control group (average $12.6 \mathrm{mg} / \mathrm{dL}$ ) and in the viral meningitis group (average $17.2 \mathrm{mg} / \mathrm{dL}$ ) studied are within the values of reference for the method used; (3) the lactate level in CSF was above normal in bacterial meningitis (average $46.2 \mathrm{mg} / \mathrm{dL}, \mathrm{SD} 33.5$ ), and in fungal meningitis (average $27.3 \mathrm{mg} / \mathrm{dL}, \mathrm{SD} 12.85$ ), the values observed are according to the ones recorded by the literature; (4) the AIDS group showed average 23.5 $\mathrm{mg} / \mathrm{dL}$ and SD 10.1; (5) the lactate values studied in CSF are elevated with statistical significance in relation to the control group, in bacterial and fungal meningitis and in the AIDS group, this was not observed in the viral meningitis group; (6) according to the data presented we may recommend the dosage of lactate in infectious processes of the CNS, mainly in viral and bacterial meningitis diagnosis.

\section{REFERENCES}

1. Ashwal S, Perkin RM, Thompson JR, Tomasi LG, Schneider S. Bacte rial meningitis in children: current concepts of neurologic management. Curr Probl Pediatr 1994;24:267-284.

2. Bland RD, Lister C, Ries JP. Cerebrospinal fluid lactic acid level and $\mathrm{pH}$ in meningitis aids in differential diagnosis. Am J Dis Child 1974 128:151-156.

3. Briem $\mathrm{H}$. Comparison between cerebrospinal fluid concentrations of glucose, total protein, chloride, lactate, and total amino acids for the differential diagnosis of patients with meningitis. Scand J Infect Dis 1983;15:277-284.

4. PaveseP, FrançoisP, Lafond JL, Kay'sSK, Bosson JL. Dosage del'acide lactique dans le liquide céphalorachidien pour le diagnostic des mé ningites bactériennes: stratégies pour le choix du seuil discriminant. Presse Méd 1997;26:551-554.

5. Carpenter RR, Petersdorf RG. The clinical spectrum of bacterial meningitis. Am J Med 1962;33:262-275.

6. Controni G, Rodriguez WJ, Hicks JM, et al. Cerebrospinal fluid lactic acid levels in meningitis. J Pediatr 1977;91:379-384.

7. Posner JB, Plum F. Independence of blood and cerebrospinal fluid lactate. Arch Neurol 1967; 16:492-496.

8. Killian JA. Lactic acid of normal and pathological spinal fluids. Proc Soc Exp Biol 1925;23:255-257.

9. Prockop LD. Cerebrospinal fluid lactic acid: clearance and effect on facilitated diffusion of glucose analogue. Neurology 1968;18:189-196.

10. Peña-Yañez A, Gil-Extremera B, Fernandez-Lloret S, Valls MAP. Importancia clínica de la lacticorraquia: I. Resultados en afecciones diversas. Rev Clin Esp 1977;145:183-187.

11. Kleine TO, Baerlocher K, Niederer V, et al. Diagnostiche Bedeutung der Lactatbestimmung im Liquor bei Meningitis. Dtsch Med Wochenschr 1979;104:1-14. 
12. Brook I, Rodriguez WJ, Controni G, Roos S. C.S.F. lactic acid for differential diagnosis of meningitis. Lancet 1979;1:1035.

13. KleineTO. Valuation of bacterial and viral antigen detection against lactate determination and leukocyte counts in CSF meningitis diagnosis. J Clin Chem Biochem 1989;27: 901-926.

14. Tuomanen $E$, Tomasz A, Hengstler B, Zak O. Therelativeroleof bacterial cell wall and capsulein theinduction of inflammation in pneumococcal meningitis. J Infect Dis 1985;151:535-540.

15. Tureen J. Effect of recombinant human tumor necrosis factor-al pha on cerebral oxygen uptake, cerebrospinal fluid lactate, and cerebral blood flow in the rabbit: role of nitric oxide. J Clin Invest 1995;95:1086-1091.

16. Park SW, Chang YS, Lee M. Effect of induced hyperglycemia on brain cell membrane function and energy metabolism during the early phase of experimental meningitis in newborn piglets. Brain Res 1998;789:195203.

17. Brook I. Stability of lactic acid in cerebrospinal fluid specimens. Am J Clin Pathol 1982;77:213-216.

18. Bustos R, Broussain MT, Tejero TMA, Rios R, Jara J. Meningitis bacteriana: identificación del agente causal por aglutinación de látex. Rev Chil Pediatr 1988;59:88-93.

19. Kleine TO. Messung un diagnostiche Bedeutung von Lactat, lactatdehydrogenaseund Lysozym im Lumball liquor vonneurologischen und psychiatrischen Patienten. In Neue Labormethoden für die Liquordiagnostik. New York: Georg Thieme, 1980:59-69.

20. Farhat CK, Soares CS, Sokolowski W, Ribeiro MA, Barbosa PR, Carvalho ES. Emprego da dosagem do lactato liquórico como método auxiliar no diagnóstico diferencial das meningites. J Pediatr (Rio de Janeiro) 1982;52:406-410.

21. Feinbloom RI, Alpert JJ. The value of routine glucose determination in spinal fluid without pleocytosis. J Pediatr 1969;75:121-123.

22. Fishman RA. Carrier transport of glucose between blood and cerebrospinal fluid. AmJ Physiol 1963;185:836-844.
23. PryceJD, GantPW, Saul KJ. Normal concentrations of lactate, glucose, and protein in cerebrospinal fluid, and diagnostic implications of abnormal concentrations. Clin Chem 1970;16:562-565.

24. LamisseF, Grenier B, ChoutetP, Rolland JC, Gautier J. Interet du dosage de l'acide lactique dans le liquide rachidien pour le diagnostic de meningites purulentes. Lyon Med 1972;228:591-595.

25. Scheld WM, Giampaolo C, Boyd J, Savory J, Wills MR, SandeMA. Cerebrospinal fluid prognostic indices in experimental pneumococcal meningitis. J Lab Clin Med 1982;100:218-229.

26. Knight JA, Dudek SM, Haymond RE. Early (chemical) diagnosis of bacterial meningitis-cerebrospinal fluid glucose, lactate, and lactatedehydrogenase compared. Clin Chem 1981;27:1431-1434.

27. D'Souza E, Mandal BK, Hooper J, Parker L. Lactic-acid concentration in cerebrospinal fluid and differential diagnosis of meningitis. Lancet 1978;2:579-580

28. Gerber J, Tumani H, Kolenda H, Nau R. Lumbar and ventricular CSF protein, leukocytes, and lactate in suspected bacterial CNS infections. Neurology 1998;51:1710-1714.

29. Genton B, Berger JP. Cerebrospinal fluid lactate in 78 cases of adult meningitis. Intensive Care Med 1990;16:196-200.

30. Krendel DA, Pilch JF, Stahl RL. Central hyperventilation in primary CNS Iymphoma: evidence implicating CSF lactic acid. N eurology 1991;41:1156-1157.

31. Gil-Extremera B, Fernández-Lloret S. Importância clínica de la lacticorraquia. Rev Clin Esp 1977;145:159-163.

32. Onorato IM, Wormser GP, Nicholas P. N ormal CSF in bacterial meningitis. JAMA 1980;244:1469-1471.

33. Cabeça HLS. A valiação crítica da dosagem delactato no líquido cefalorraqueno em moléstias infecciosas do sistema nervoso central. Dissertação de Mestrado, Faculdade de Medicina da Universidade de São Paulo. São Paulo, 2000. 